\title{
Respon Produksi dan Kualitas Buah Salak Gula Pasir (Salacca zalacca var. Gula Pasir) terhadap Dosis Pupuk Hayati Mikoriza
}

\author{
NADA SAHARA, I NYOMAN RAI ${ }^{*}$, DAN I WAYAN WIRAATMAJA \\ Program Studi Agroekoteknologi Fakultas Pertanian Universitas Udayana \\ Jl. P.B. Sudirman Denpasar Bali 80231 Bali \\ ${ }^{*}$ E-mail: rainyoman@unud.ac.id
}

\begin{abstract}
Production and Quality of Salak Gula Pasir (Salacca zalacca var. Gula Pasir) in Response to Application of Dosages of Mycorrhiza Biofertilizer. Mycorrhiza is a fungus that live symbiosis mutualism with the root of the plant. Mycorrhiza has several benefits that improve the soil structure an increase the absorption of nutrients and water for plant. This research aimed to know response of production and quality of salak gula pasir (salacca zalacca var. Gula Pasir) fruit to dose of mycorrhiza biofertilizer application. This study used a randomized block design (RBD) with 4 levels of mycorrhiza biofertilizer dosages, i.e. 0, 50, 100, and 150 spores per $500 \mathrm{~g}$ of carrier media. Each treatment was repeated 10 times. The results showed mycorrhiza dose of 50,100, and 150 spores per $500 \mathrm{~g}$ carrier media increase the amount of fruits bunches in each plant, the sweetness level of fruit and root infections/colonization by mycorrhiza.
\end{abstract}

Keywords: biofertilizer, dose, mycorrhiza, salak Gula Pasir

\section{PENDAHULUAN}

Salak merupakan salah satu tanaman asli Indonesia dengan kandungan gizi berupa vitamin, mineral, protein, kalori dan karbohidrat. Komoditas salak bagi Provinsi Bali memiliki nilai ekonomis tinggi, baik sebagai buah segar maupun olahan. Salah satu varietas salak yang sangat disukai oleh konsumen adalah salak Gula Pasir.
Salak Gula Pasir (Salacca zalacca var. Gula Pasir) berasal dari Kabupaten Karangasem, dilepas sebagai varietas unggulan nasional pada tahun 1994 berdasarkan Keputusan Menteri Pertanian Nomor 584/Kpts/Tp.240/7/94. Salak Gula Pasir memiliki beberapa kelebihan dibandingkan dengan salak jenis lain. Hal ini berkaitan dengan rasa buah manis walaupun umurnya masih muda, tidak ada 


\section{NADA SAHARA et al. Respon Produksi dan Kualitas Buah Salak Gula Pasir...}

rasa asam, daging buah tebal, dan tidak melekat pada biji (Rai et al., 2010).

Sentra produksi salak di Kabupaten Karangasem terdapat di Kecamatan Bebandem, Kecamatan Selat, Kecamatan Rendang dan Kecamatan Sidemen. Penghasil salak terbesar terdapat di Kecamatan Bebandem dengan luas panen 3.444 ha dan total produksi 11.087 ton, sedangkan produksi total salak di Kabupaten Karangasem pada tahun 2018 sebesar 21.317 ton (BPS Kabupaten Karangasem, 2018).

Kebutuhan unsur hara pada tanaman salak Gula Pasir dapat dipenuhi dengan pemupukan yang bijaksana dan ramah lingkungan. Penggunaan pupuk anorganik secara intensif dapat menurunkan kualitas tanah sehingga diperlukan pupuk hayati dengan memanfaatkan mikoriza sebagai agen hayati yang ramah lingkungan agar kualitas tanah pada perkebunan salak tidak cepat menurun. Mikoriza atau sering disebut fungi arbuskula mikroriza (FMA) adalah cendawan yang hidup bersimbiosis mutualisme dengan perakaran tanaman inang. Menurut Widnyana (2018) FMA dapat membantu penyerapan unsur hara dalam tanah sehingga dapat meningkatkan pertumbuhan tanaman, penghalang infeksi patogen akar, meningkatkan ketersediaan air bagi tanaman dan meningkatkan aktivitas fitohormon. Selain itu, mikoriza dapat memperbaiki struktur tanah dengan dihasilkannya senyawa glucoprotein flomalin yang sangat berkolerasi dengan peningkatan kemantapan agregat tanah (Pulungan, 2018).

Penggunaan mikoriza sebagai pupuk hayati keberhasilannya sangat ditentukan oleh berbagai hal, salah satuya adalah dosis spora yang digunakan. Respon tanaman yang diberikan mikoriza akan berbeda dengan tanaman tanpa mikoriza, hal ini sesuai dengan penelitian Sudiarti (2018), bahwa pemberian FMA pada tanaman kedelai edamame (Glycine max) berpengaruh nyata terhadap pertumbuhan tinggi tanaman, jumlah daun dan jumlah cabang produktif dibandingkan tanpa pemberian FMA. Taraf dosis spora mikoriza yang berbeda dapat mempengaruhi pertumbuhan dan hasil tanaman. Menurut Pratama et al. (2019), taraf perlakuan FMA dosis 0, 5, 10 dan 15 g/tanaman pada tanaman kacang merah (Phaseolus vulgaris L.) lokal Garut, didapatkan dosis $10 \mathrm{~g} /$ tanaman memberikan pengaruh terbaik terhadap jumlah daun umur 35, 40 dan 45 hari setelah tanam, luas daun, bobot kering tanaman, jumlah polong per tanaman, hasil biji basah per tanaman 
dan hasil biji basah per plot. Sedangkan menurut Lele et al., (2018), dosis 50 spora endomikoriza pada tanaman jagung sudah cukup untuk meningkatkan pertumbuhan tanaman tetapi berbeda tidak nyata dengan pemberian dosis 100 dan 150 spora. Rai et al. (2020) juga melaporkan bahwa pemberian mikoriza meningkatkan produksi buah per pohon dan kaliatas buah salak, namun belum tersdia informasi mengenai dosis pupuk mikoriza terbaaik untuk salak Gula pasir. Berdasarkan uraian tersebut, perlu dilakukan penelitian untuk mengkaji dosis spora mikoriza yang tepat sehingga didapatkan produksi dan kualitas buah salak Gula Pasir yang terbaik.

\section{BAHAN DAN METODE}

Penelitian ini dilaksanakan dari bulan Mei 2019 sampai Januari 2020 di Kebun Salak Gula Pasir milik petani di Banjar Karanganyar, Desa Sibetan, Kecamatan Bebandem, Kabupaten Karangasem. Pengamatan kualitas buah dilaksanakan di Laboratorium Agronomi dan Hortikultura Fakultas Pertanian Universitas Udayana. Isolasi mikoriza dilakukan di Laboratorium Sumber Daya Genetik dan Biologi Molekuler Universitas Udayana.

Bahan yang digunakan dalam penelitian ini adalah tanaman salak Gula
Pasir, spora mikoriza, pasir vulkanik sebagai media pembawa, tisue, kertas label, kantong plastik, air kran, aquades, glukosa $60 \%, \mathrm{KOH} 10 \%, \mathrm{H}_{2} \mathrm{O}_{2} 3 \%$, lactoglycerol, dan trypan blue. Alat-Alat yang digunakan meliputi pinset, mesin sentrifuse, tabung sentrifuse, timbangan, cangkul, pelubang kertas, gunting, toples, oven, sendok, jangka sorong, cawan petri, gelas objek, jarum ose, gelas beaker, tabung reaksi, mikroskop stereo,satu set penyaringan dengan diameter lubang $1 \mathrm{~mm}, 500 \mu \mathrm{m}$, $212 \mu \mathrm{m}, 106 \mu \mathrm{m}$ dan $53 \mu \mathrm{m}$, cooll box, Chorophyll Meter SPAD-502, refractometer, cover glass, microwave.

Penelitian menggunakan Rancangan Acak Kelompok (RAK) dengan perlakuan, dosis spora mikoriza yang terdiri atas 4 taraf, yaitu: $D_{0}(0$ spora per 500 g media pembawa), $D_{1}$ (50 spora per 500 g media pembawa), $\mathrm{D}_{2}$ (100 spora per 500 g media pembawa), dan $\mathrm{D}_{3}$ (150 spora per $500 \mathrm{~g}$ media pembawa). Setiap perlakuan di ulang sebanyak 10 kali.

Eksplorasi dilakukan dengan mengambil sampel tanah pada perakaran salak Gula Pasir tempat penelitian. Sampel diambil dari tiga lokasi, disetiap lokasi diambil lima titik, kemudian sampel tanah dikompositkan menjadi satu. Sampel tanah diambil pada jarak $10 \mathrm{~cm}$ dari pangkal 


\section{NADA SAHARA et al. Respon Produksi dan Kualitas Buah Salak Gula Pasir...}

batang tanaman dengan kedalaman $5-15 \mathrm{~cm}$ dari permukaan tanah karena spora mikoriza umumnya banyak ditemukan pada bagian top soil (Nurhandayani et al., 2013). Sampel tanah yang diambil sebanyak $3 \mathrm{~kg}$ per titik (15 kg per lokasi), kemudian dimasukkan ke dalam kantong plastik, diberi label, dan dibawa ke laboratorium untuk disiolasi spora mikorizanya.

Metode untuk isolasi spora yang digunakan adalah metode penyaringan basah menurut Pacioni (1992) dan dilanjutkan dengan teknik sentrifugasi dari Brunndret et al. (2008). Prosedur kerja teknik penyaringan basah adalah mencampurkan sampel tanah sebanyak $50 \mathrm{~g}$ dimasukkan ke dalam gelas beker $1000 \mathrm{ml}$ dilarutkan dalam $1.000 \mathrm{ml}$ air dan diaduk selama 3 menit sampai homogen, kemudian didiamkan selama 3 menit agar partikelpartikel besar mengendap. Selanjutnya disaring dalam satu set saringan dengan ukuran diameter lubang 1 mm, $500 \mu \mathrm{m}, 212$ $\mu \mathrm{m}, 106 \mu \mathrm{m}$ dan $53 \mu \mathrm{m}$ secara berurutan dari atas ke bawah (dari diameter lubang terbesar ke terkecil). Setelah saringan ukuran diameter lubang $1 \mathrm{~mm}$ dan $500 \mu \mathrm{m}$ dilepas kemudian tanah yang tersisa pada saringan $106 \mu \mathrm{m}$ dan $53 \mu \mathrm{m}$ dibilas dengan air kran lalu dipindahkan ke tabung sentrifus, ditambahkan larutan glukosa $60 \%$ sebanyak $25 \mathrm{ml}$, lalu disentrifus dengan kecepatan $2.000 \mathrm{rpm}$ selama 3 menit. Larutan supernatan hasil sentrifus yang masih mengandung larutan gula kemudian dibilas dengan air pada saringan dengan diameter lubang $53 \mu \mathrm{m}$ dan hasil bilasan diletakkan pada cawan petri, selanjutnya diamati dibawah mikroskop stereo (dengan menggunakan pembesaran 40-100 kali) untuk mengetahui jumlah spora yang terdapat pada $50 \mathrm{~g}$ tanah sampel yang telah disaring. Pembuatan prototipe pupuk hayati mikoriza sesuai perlakuan taraf dosis spora dilakukan dengan menghitung spora yang terdapat pada cawan petri dibilas dengan aquades kemudian dimasukan ke dalam toples yang berisi pasir vulkanik sebanyak 500 g sebagai media pembawa. Prototipe pupuk hayati tersebut kemudian diaplikasikan pada pohon salak Gula Pasir sesuai dosis perlakuan.

Pohon salak Gula Pasir yang akan digunakan pada penelitian ini sudah biasa berbuah dan dapat produksi dengan baik. Sebelum diberikan pupuk hayati, dilakukan pembersihan areal kebun seperti penghilangan gulma atau tumbuhan pengganggu untuk mencegah persaingan unsur hara antara pohon salak dengan gulma, mencegeah kontaminasi hama penyakit, serta dilakukan penggemburan 
tanah disekitar area pertanaman untuk memperbaiki kondisi tanah. Pemberian pupuk dilakukan dengan cara menggali tanah di sekeliling pohon pada jarak $20 \mathrm{~cm}$ dari pangkal pohon, kedalaman $20 \mathrm{~cm}$ dan lebar $30 \mathrm{~cm}$. Pemupukan disesuaikan dengan dosis perlakuan $(0,50,100$ dan 150 spora per $500 \mathrm{~g}$ media pembawa pasir vulkanik), dengan cara disebarkan merata ke dalam lubang, kemudian lubang tersebut ditimbun dengan tanah secara tipis. Variabel yang diamati meliputi jumlah tandan buah per tanaman, berat buah per tanaman, berat per buah, tingkat kemanisan buah, dan infeksi akar. Data hasil pengamatan dianalisis sesuai rancangan yang digunakan dan dilanjutkan dengan Uji BNT taraf 5\%.

\section{HASIL DAN PEMBAHASAN}

Hasil analisis statistika menunjukkan perlakuan dosis spora mikoriza berpengaruh nyata terhadap jumlah tandan buah per tanaman dan tingkat kemanisan buah, bepengaruh sangat nyata terhadap infeksi/kolonisasi akar oleh mikoriza, tetapi berpengaruh tidak nyata terhadap berat buah per tanaman dan berat per buah. Signifikasi pengaruh dosis spira mikroiza terhadap variabel yang diamati seperti pada Tabel 1.

Tabel 1. Signifikasi pengaruh dosis spora mikoriza terhadap variabel yang diamati

\begin{tabular}{clc}
\hline No & \multicolumn{1}{c}{ Variabel } & Perlakuan Dosis \\
\hline 1 & Jumlah tandan buah per tanaman (buah) & $*$ \\
2 & Berat buah pertanaman $(\mathrm{g})$ & $\mathrm{ns}$ \\
3 & Berat perbuah $(\mathrm{g})$ & $\mathrm{ns}$ \\
4 & Tingkat kemanisan buah $\left({ }^{\%}\right.$ Brix $)$ & $*$ \\
5 & Infeksi akar $(\%)$ & $* *$ \\
\hline & Keterangan: $\mathrm{ns}:$ : Berpengaruh tidak nyata $(\mathrm{P} \geq 0,05)$ \\
& $*:$ Berpengaruh nyata $(\mathrm{P}<0,05)$ \\
& $* *:$ Berpengaruh sangat nyata $(\mathrm{P}<0,01)$ &
\end{tabular}

Jumlah tandan buah per tananam pada pemberian mikoriza dosis $\mathrm{D}_{1}, \mathrm{D}_{2}$ dan $\mathrm{D}_{3}$ nyata lebih tinggi dibandingkan dengan tanpa pemberian mikoriza $\left(\mathrm{D}_{0}\right)$ (Tabel 2). Jumlah tandan buah tertinggi diperoleh pada perlakuan $\mathrm{D}_{1}(2,33$ buah) dan terendah pada $\mathrm{D}_{0}\left(1,44\right.$ buah), namun antara $\mathrm{D}_{1}, \mathrm{D}_{2}$ dan $\mathrm{D}_{3}$ berbeda tidak nyata. Lebih tingginya jumlah tandan buah per tanaman pada $\mathrm{D}_{1}$, $D_{2}$ dan $D_{3}$ berkoreliasi dengan lebih 


\section{NADA SAHARA et al. Respon Produksi dan Kualitas Buah Salak Gula Pasir...}

tingginya kolonisasi akar oleh mikoriza pada taraf tersebut dibandingkan pada $\mathrm{D}_{0}$. Pada Tabel 2 dapat dilihat, infeksi akar oleh mikoriza pada $\mathrm{D}_{0}$ hanya $0,28 \%$, nyata lebih rendah dibandingkan pada $\mathrm{D}_{1}, \mathrm{D}_{2}$ dan $\mathrm{D}_{3}$ dengan infeksi akar berturut-turut $0,83 \%$, $0,84 \%$ dan $0,83 \%$ atau terjadi peningkatan persentase infeksi akar oleh mikoriza pada $\mathrm{D}_{1}, \quad \mathrm{D}_{2}$ dan $\mathrm{D}_{3}$ berturut-turut $196,64 \%$, 200,00\%, dan 196,64\% dibandingkan pada $\mathrm{D}_{0}$. Meningkatnya infeksi akar pada tanaman salak yag diberikan mikrosa dengan dosis $D_{1}, D_{2}$ dan $D_{3}$ sesuai dangan hasil penelitian Junita (2015) yang menyatakan bahwa pemberian mikoriza mampu meningkatkan persentase infeksi akar. Selain itu, sesuai juga dengan hasil penelitian Rai et al. (2020) bahwa pada perkebunan salak organik, tanaman salak yang diberikan pupuk hayati mikoriza persentase kolonisasi akar oleh mikoriza mencapai $100 \%$ dan meningkat nyata dibandingkan tanpa mikoriza dengan persentase infeksi akar hanya 23,14\%. Infeksi mikoriza yang tinggi pada akar tanaman menurut Prasasti et al., (2013) memberikan dampak positif bagi tanaman karena mikoriza membantu peran akar dalam menyerap air dan hara dari tempat yang jauh dari jangkauan akar melalui hifa eksternal mikoriza yang tumbuh ekstensif dan meluas, jauh lebih panjang dan dalam dari akar tanaman.

Tabel 2. Pengaruh dosis mikoriza terhadap jumlah tandan buah per tanaman, berat buah per tanaman, berat per buah, tingkat kemanisan buah, dan infeksi akar (\%)

\begin{tabular}{cccccc}
\hline Perlakuan & $\begin{array}{c}\text { Jumlah tandan } \\
\text { buah per tanaman } \\
\text { (buah) }\end{array}$ & $\begin{array}{c}\text { Berat buah } \\
\text { per tanaman } \\
(\mathrm{g})\end{array}$ & $\begin{array}{c}\text { Berat per } \\
\text { buah }(\mathrm{g})\end{array}$ & $\begin{array}{c}\text { Tingkat } \\
\text { kemanisan } \\
\text { buah }\left({ }^{\%} \text { Brix }\right)\end{array}$ & $\begin{array}{c}\text { Infeksi/ } \\
\text { kolonisasi } \\
\text { akar }(\%)\end{array}$ \\
\hline $\begin{array}{c}\text { Dosis Mikoriza } \\
\mathrm{D}_{0}\end{array}$ & $1,44 \mathrm{~b}$ & $834,81 \mathrm{a}$ & $32,30 \mathrm{a}$ & $16,85 \mathrm{c}$ & $0,28(0,52) \mathrm{b}$ \\
$\mathrm{D}_{1}$ & $2,33 \mathrm{a}$ & $804,94 \mathrm{a}$ & $46,39 \mathrm{a}$ & $17,00 \mathrm{bc}$ & $0,83(0,90) \mathrm{a}$ \\
$\mathrm{D}_{2}$ & $2,22 \mathrm{a}$ & $906,26 \mathrm{a}$ & $44,19 \mathrm{a}$ & $18,27 \mathrm{ab}$ & $0,84(0,91) \mathrm{a}$ \\
$\mathrm{D}_{3}$ & $2,00 \mathrm{a}$ & $845,37 \mathrm{a}$ & $37,46 \mathrm{a}$ & $18,64 \mathrm{a}$ & $0,83(0,91) \mathrm{a}$ \\
\hline BNT & 0,58 & 302,12 & 21,59 & 1,44 & 0,14 \\
\hline
\end{tabular}

Keterangan :-angka yang diikuti huruf sama pada kolom dan perlakuan yang sama menunjukkan berbeda tidak nyata pada uji BNT taraf $5 \%$.

- angka-angka yang dikurung menunjukkan angka hasil transformasi ke $\sqrt{x}_{\mathrm{x}}+1$ sedangkan angka di depan tanda kurung merupakan nilai asli dari rata-rata

Tabel 2 menunjukkan, walaupun jumlah tandan buah per tanaman dan infeksi akar meningkat nyata pada taraf $\mathrm{D}_{1}, \mathrm{D}_{2}$ dan $\mathrm{D}_{3}$ dibandingkan pada $\mathrm{D}_{0}$ tetapi berat buah 
per tanaman dan berat per buah pada $\mathrm{D}_{1}, \mathrm{D}_{2}$ dan $\mathrm{D}_{3}$ berbeda tidak nyata dibandingkan dengan $\mathrm{D}_{0}$. Hasil penelitian ini berbeda dengan hasil penelitian Rai et al. (2020) bahwa meningkatnya infeksi akar pada tanaman yang diberikan pupuk mikoriza menyebabkan berat buah per tanaman dan berat per buah meningkat nayata dibandingkan dengan tanpa pemberian pupuk mikoriza. Disebutkan bahwa pada pohon salak yang diberikan pupuk mikoriza, berat buah per tanaman dan berat per buah masing-masing 790,80 g dan 47,61 g sedangkan pada pohon yang tidak diberikan pupuk mikroza berat buah per tanaman dan berat per buahnya hanya $553,81 \mathrm{~g}$ dan 44,09 g. Hasil yang diperoleh dalam penelitian ini juga berbeda dengan hasil penelitian Kusuma (2018) bahwa berat buah per tanaman salak Gula Pasir tertinggi diperoleh pada pemberian mikoriza dikombinasikan dengan seresah daun yaitu 2536, $67 \mathrm{~g}$ dan berbeda nyata dengan kontrol. Berat buah per tanaman dan berat per buah yang berbeda tidak nyata antara tanaman salak yang diberikan mikoriza dengan tanpa mikoriza dalam penelitian ini diduga berkaitan dengan kondisi pertanaman salak tempat penelitian yang terkena dampak abu letusan Gunung Agung dari akhir tahun 2018 sampai tahun 2019.
Menurut informasi petani pemilik, paparan abu letusan Gunung Agung yang menimpa perkebunan salak di Sibetan, termasuk pohon salak milik petani yang dipakai penelitian, menyebabkan produksi salak milik petani turun tajam. Hal tersebut terbukti dari hasil penelitian ini, walaupun kemampuan tanaman menyerap air dan hara meningkat pada pemberian mikoriza sehingga menyebabkan jumlah tandan buah per tanaman meningkat, tetapi karena pembentukan dan pertumbuhan buah terganggu karena adanya tempelan abu letusan Gunung Agung pada permukaan daun, menyebabkan berat buah per tanaman dan berat per buah pada tanaman yang diberikan mikoriza dosis $D_{1}, D_{2}$ dan $D_{3}$ berbeda tidak nyata dibandingkan dengan $\mathrm{D}_{0}$. Diduga abu letusan Gunung Agung yang mengenai daun salak mengandung senyawa tertentu yang bersifat mengganggu proses fotosintesis sehingga meningkatnya jumlah tandan buah yang terbentuk tidak diikuti oleh meningkatnya berat buah pertanaman. Menurut Prayoda et al. (2015), terganggunya proses pertumbuhan buah, menurunkan pembesaran buah dan persentase fruit-set (jumlah bunga yang berkembang menajdi buah) sehingga menyebabkan produksi buah rendah. 


\section{NADA SAHARA et al. Respon Produksi dan Kualitas Buah Salak Gula Pasir...}

Walaupun pemberian mikoriza dosis $\mathrm{D}_{1}, \mathrm{D}_{2}$ dan $\mathrm{D}_{3}$ memberikan berat buah per tanaman dan berat per buah berbeda tidak nyata dengan $D_{0}$, tetapi dosis $D_{1}, D_{2}$ dan $D_{3}$ meningkatkan kemanisan buah. Tabel 1 menunjukkan, tingkat kemanisan buah tertinggi diperoleh pada $\mathrm{D}_{3}$ yaitu 18,64 ${ }^{\%}$ Brix dan berbeda nyata dengan tingkat kemanisan buah terrendah pada $\mathrm{D}_{0}(16,85$ ${ }^{\%}$ Brix), tetapi antara $\mathrm{D}_{3}$ dengan $\mathrm{D}_{2}$ berbeda tidak nyata. Data tersebut menunjukkan bahwa pemberian mikoriza di musim kemarau (bulan Mei) pada saat tanaman salak di lokasi penelitian berada pada periode di luar musim (off-season) atau di luar masa berbunga pada musimnya (bulan Agustus) menyebabkan tingkat kemanisan buah meningkat. Hal yang sama dilaporkan oleh Rai et al. (2020) bahwa salak yang diberikan pupuk mikoriza tingkat kemanisan buahnya $13,72{ }^{\%}$ Brix, meningkat nyata dibandingkan dengan tanpa pemberian pupuk mikoriza dengan tingkat kemanisan buah hanya $11,89{ }^{\%}$ Brix. Lebih tingginya kemanisan buah pada salak yang dipupuk mikoriza disebutkan karena peningkatan nyata kandungan gula reduksi dan sukrosa pada daging buah. Menurut Mardianto (2014), kuantitas dan kualitas produksi buah pada tanaman buah-buahan dipengaruhi oleh faktor lingkungan tumbuh dan alokasi fotosintat ke organ buah. Selanjutnya Nurjannah et al. (2013) menyatakan bahwa pembentukan dan pengisian buah sangat dipengaruhi oleh unsur hara $(\mathrm{N}, \mathrm{P}$ dan $\mathrm{K})$ yang akan digunakan dalam proses fotosintesis yaitu sebagai penyusun karbohidrat, lemak, protein, mineral dan vitamin yang akan ditranslokasikan ke organ penyimpanan buah.

\section{SIMPULAN}

Pemberian mikoriza dosis 50, 100 dan 150 spora per 500 g media pembawa meningkatkan jumlah tandan buah per tanaman masing-masing $61,80 \%, 54,17 \%$, dan $38,89 \%$, meningkatkan kemanisan buah masing-masing $0,15{ }^{\%} \mathrm{Brix}, 1,42{ }^{\%} \mathrm{Brix}$, dan $1,79{ }^{\%}$ Brix, serta meningkatkan infeksi akar oleh mikoriza masing-masing 196,64\%, $200,00 \%$, dan $196,64 \%$.

\section{DAFTAR PUSTAKA}

BPS (Badan Pusat Statistik) Karangasem. (2018). Produksi (ton) buah salak. Kabupaten Karangasem dalam Angka 2018.

https://karangasemkab.bps.go.id/publi cation/ 2018/08/16/f1bf896039fff9ab187cf3c 5/kabupaten-karang-asem-dalamangka-2018. html. [5 Agustus 2019]. Brundrett, M. C. (2008). Mycorrhiza Associations: the web resource. Section 1. Introduction School of 
Plant Biology, the University of Western, Australia.

Junita, E. (2015). Pengaruh Media Tanam dan Fungi Mikoriza Arbuskular terhadap Pertumbuhan dan Hasil Tanaman Cabai Merah (Capsicum annum L.). Skripsi. Fakultas Pertanian. Universitas Syiah Kuala. Banda Aceh.

Kusuma, N. M. (2018). Respon Pemupukan terhadap Kandungan Hara Daun dan Kandungan Karbohidrat Daun serta Hasil dan Kualitas Hasil Salak Gula Pasir (Salacca zalazza var. Gula Pasir) di Luar Musim. Skripsi. Universitas Udayana.

Lele, O. K., Rai, I. N., \& Suada, I. K. (2018). Uji Efektifitas Endomikoriza Indigenus terhadap Pertumbuhan Tanaman Jagung (Zea mays L.). Agrotrop. 8(1): $20-27$.

Mardianto, R. (2014). Pertumbuhan dan Hasil Tanaman Cabai (Capsicum annum L.) dengan Pemberian Pupuk Organik Cair Daun Tithonia diversifolia dan Gamal. Universitas Tamansiswa Padang. Padang.

Nurhandayani, R., Linda, R., \& Khotimah, S. (2013). Inventarisasi Jamur Mikoriza Vesikular Asbukular dari Rhizosfer Tanah Gambut Tanaman Nanas (Ananas comosus L. Merr). Protobiont. 2(3): 146-251.

Nurjannah, I. F., Santoso, E., \& Anggorowati, D. (2013). Pengaruh beberapa Jenis Pupuk Kandang terhadap Pertumbuhan dan Hasil Tanaman Cabai Merah pada Tanah Gambut.

http://jurnal.untan.ac.id/index.php/jsp p/article/view/1185 [10 April 2020\}.

Pacioni, G. (1992). Wet Sieving and Decanting Techniques for The Extraction of Spores of VA Mycorrhyzal Fungi. Methods in
Microbiology. Academic Press Inc. San Diego 24: 317-322.

Prayoda, R., Juhriah, Hasyim, Z., \& Suhadiyah, S. (2015). Pertumbuhan dan Produksi Tanaman Melon Cucumis melo L. Var. Action dengan Aplikasi Vermikompos Padat. Jurusan Biologi Fakultas MIPA. Universitas Hassanudin Makasar. Makasar.

Pulungan, A. S. S. (2018). Tinjauan Ekologi Fungi Mikoriza Arbuskula. Jurnal Biosains 4(1): 17-22.

Prasasti, O. H., Purwani, K. I., \& Nurhatika, S. (2013). Pengaruh Mikoriza Glomus fasciculatum terhadap Pertumbuhan Vegetatif Tanaman Kacang Tanah yang Terinfeksi Patogen Sclerotium rolfsii. Jurnal Sains dan Seni Pomits 2(2): 74-78.

Pratama, R. A., Nizar, A., \& Siswancipto, T. (2019). Pengaruh Pemberian berbagai Dosis Cendawan Mikoriza Arbuskular (CMA) dan Pupuk Fosfat Alam terhadap Pertumbuhan dan Hasil Kacang Merah (Phaseolus Vulgaris L.) Lokal Garut. Jurnal Agro Wiraldra. 2(2): 43-51.

Rai, I. N., Semarjaya, C. G. A., \& Wiraatmaja, I. W. (2010). Studi Fenologi Pembuahan Salak Gula Pasir Sebagai Upaya Mengatasi Kegagalan Fruit-Set. Jurnal Hortikultura. 20(3): 216-222.

Rai, I. N., Suada, I. K., Wiraatmaja, I. W., \& Astiari, N. K. A. (2020). Effectiveness of indigenous endomycorrhizal biofertilizer prototype on organic salak leaves and fruits in Bali. BIOTROPIA The Southeast Asian Journal of Biology. Article in Press. https://doi.org/10.11598/btb.0.0.0.133 3. 
NADA SAHARA et al. Respon Produksi dan Kualitas Buah Salak Gula Pasir...

Sudiarti, D. (2018). Pengaruh Pemberian Cendawan Mikoriza Arbuskula (CMA) terhadap Pertumbuhan Kedelai Edamame (Glycin max). Jurnal Sain Health. 2(2): 5-11.

Widyana. (2018). Isolasi dan Identifikasi Endomikoriza di Perakaran Tnaman Jagung (Zea mays L.) Dataran Rendah serta Perbanyakannya. Skripsi. Universitas Udayana. 